\title{
The rise of behavioural economics
}

\author{
The Nobel Prize in Economic Sciences this year, in honouring the work of Richard H. Thaler, highlights the growing \\ impact of behavioural economics in science and policy.
}

T he Nobel Prize in Economic Sciences was set up in 1969. Since then, and including this year's recipient, Richard H. Thaler from The University of Chicago Booth School of Business, $6 \%$ of economics Nobel laureates could be described as behavioural economists ${ }^{1}$. They seem to form a very small fraction of all recipients; however, with one exception, these awards were made in the new millennium, reflecting the increasing visibility of the discipline.

Neoclassical economics has dominated the field of microeconomics since the late nineteenth century. In neoclassical economics, individuals are rational utility maximizers, making inferences and decisions on the basis of perfect information. In its current incarnation, behavioural economics arose in the second half of the twentieth century by integrating insights from economics and psychology. It is motivated by the observation that, in practice, individual and collective human behaviour deviates systematically from normative principles of economic behaviour. Humans are characterized by bounded rationality, bounded willpower and bounded self-interest ${ }^{2}$ : cognitive limitations constrain human judgement and choice, people occasionally make choices that are against their own interests and people are often altruistic.

Although the two fields have not seen eye to eye, they each illuminate economic behaviour at different levels of explanation. It is behavioural economics, however, that is currently experiencing significant prominence in the policy domain, and Thaler's work has been instrumental in this respect.

In his 40-year-long academic career, Thaler has been one of the key contributors to the body of research that spurred the establishment of behavioural economics and behavioural finance as fields of study. The Royal Swedish Academy of Sciences in its press release announcing the 2017 economics prize highlighted Thaler's contributions in three areas: limited rationality, social preferences and lack of self-control. Outside of academic circles, Thaler is probably best known for his applied work on behaviour change through

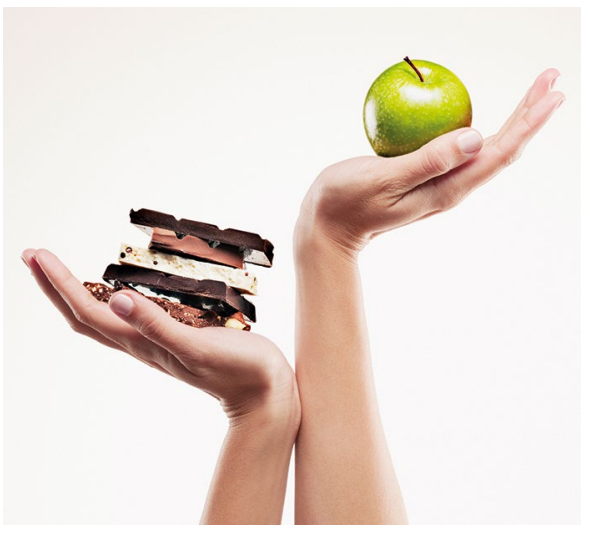

Credit: Chris Ryan / OJO Images / Getty

nudges. In a 2003 academic article ${ }^{3}$, Thaler and legal scholar Cass R. Sunstein advocated for 'libertarian paternalism': the idea that it is possible for organizations to guide people's choices towards outcomes beneficial to them, while maintaining freedom of choice. They argued that design choices, be they by governments or private institutions, are inevitable; given that people are not always rational but tend to err in systematic ways, it is possible to design choices in such a way that, although individuals still have the freedom to choose, they are 'nudged' towards a choice that is in their best interest.

Nudge, a 2008 book-length promulgation of libertarian paternalism and how it can be applied in public policy through nudges that steer people towards decisions beneficial to their health and well-being, proved highly influential ${ }^{4}$. The book and approach described therein inspired the setting up of a 'nudge unit', the Behavioural Insights Team, as a part of the UK government in 2010. Thaler advised the UK government on the unit's launch and the Behavioural Insights Team has spawned branches in a number of countries, including Australia and the United States. Barack Obama established a similar unit - the Social and Behavioural Sciences Team - as part of the US federal government and in 2015 issued an executive order instructing federal government agencies to apply insights from behavioral science to their programmes.

Libertarian paternalism has not been without vocal critics, both within the academic world and in the public domain. Philosophers have questioned the ethics of nudging ${ }^{5}$, some fellow behavioural economists have questioned the inevitability of paternalism in enabling behaviour change ${ }^{6}$, while the public has occasionally voiced concerns about being influenced without their knowledge ${ }^{7}$. Objections notwithstanding, the adoption of nudging and behavioural insights in public policy reflects the burgeoning role behavioural economics plays in public policy: governments worldwide are increasingly aware that the typical policy tools of legislating and informing are insufficient to bring about behavioural change.

To mark the occasion of this year's Nobel Prize in Economic Sciences, we have put together a collection of behavioural economics articles published this year in Nature Human Behaviour. From a typology of nudges for health-related behaviour change to an examination of under what conditions people will cooperate to sustain a public good, the research and opinion published in our pages exemplifies some of the key contributions this fast-growing field is making to science and policy. Behavioural economics is a core discipline in Nature Human Behaviour and we strongly encourage the submission of theoretical, empirical and applied research that furthers our understanding of real-world economic choices and behaviour change.

Published online: 7 November 2017 https://doi.org/10.1038/s41562-017-0252-9

\section{References}

1. Shiller, R. Richard Thaler is a controversial Nobel prize winner - but a deserving one. The Guardian (11 October 2017); https:/ www.theguardian.com/world/2017/oct/11/richard-thaler-nobelprize-winner-behavioural-economics

2. Mullainathan, S. \& Thaler, R. H. Behavioral Economics NBER Working Papers 7948 (National Bureau of Economic Research, 2000).

3. Thaler, R. H. \& Sunstein, C. R. Am. Econ. Rev 92, 175-179 (2003).

4. Thaler, R. H. \& Sunstein, C. R. Nudge: Improving Decisions about Health, Wealth, and Happiness (Yale Univ. Press, New Haven, CT, 2008)

5 White, M. D. The Manipulation of Choice: Ethics and Libertarian Paternalism (Palgrave Macmillan, New York, NY, 2013).

6 Grüne-Yanoff, T. \& Hertwig, R. Minds Mach. 26 149-183 (2016).

7 Dunt, I. Nudge nudge, say no more. Brits' minds will be controlled without us knowing it. The Guardian (5 February 2014); https://www.theguardian.com/commentisfree/2014/ feb/05/nudge-say-no-more-behaviouralinsights-team 